\title{
Energy values of crude glycerin for broilers
}

[Valores energéticos da glicerina bruta para frango de corte]

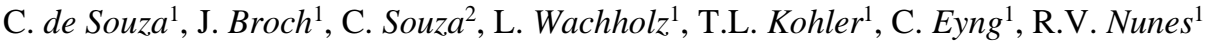 \\ ${ }^{1}$ Universidade Estadual do Oeste do Paraná - Marechal Cândido Rondon, PR \\ ${ }^{2}$ Universidade Tecnológica Federal do Paraná - Dois Vizinhos, PR
}

\begin{abstract}
The energetic values of crude glycerin (CG) were determined for broilers at different ages using the method proposed by Matterson and by polynomial regressions. Two trials were performed with broilers from 11 to 21 and from 31 to 41 days of age. The birds were distributed in a completely randomized experimental design with a reference ration (RR), without $\mathrm{CG}$, and three ration tests with replacement of 5\%, $10 \%$, and $15 \%$ of RR by CG. The metabolizable energy values were calculated by the Matterson method, and the apparent metabolizable energy (AME) values were used in polynomial regression analysis. The mean values of $A M E$, apparent corrected for nitrogen balance $\left(\mathrm{AME}_{\mathrm{n}}\right)$, metabolizable coefficient of gross energy (CAMEB), and corrected for nitrogen balance $\left(\mathrm{CAMEB}_{\mathrm{n}}\right)$ of $\mathrm{CG}$, for the phase from 11 to 21 days by the Matterson method were $10.08 \mathrm{MJ} \mathrm{kg}^{-1}, 10.04 \mathrm{MJ} \mathrm{kg}^{-1}, 67.06 \%$, and $66.74 \%$, respectively. The inclusion of CG presented an increasing linear effect for CAMEB and $\mathrm{CAMEB}_{\mathrm{n}}$ in this period. From 31 to 41 days, these values were $10.38 \mathrm{MJ} \mathrm{kg}^{-1}, 10.27 \mathrm{MJ} \mathrm{kg}^{-1}, 69.02 \%$, and $62.24 \%$, respectively. The predicted $\mathrm{AME}_{\mathrm{n}}$ value through the polynomial regression equations was $10.49 \mathrm{MJ} \mathrm{kg}^{-1}$ and $10.18 \mathrm{MJ} \mathrm{kg}^{-1}$, respectively. According to the equations proposed by Matterson, the crude glycerin $\mathrm{EMA}_{\mathrm{n}}$ values for broilers from 11 to 21 and 31 to 41 days of age were $10.04 \mathrm{MJ} \mathrm{kg}^{-1}$ and $10.26 \mathrm{MJ} \mathrm{kg}^{-1}$, respectively. According to Adeola's method the $\mathrm{AME}_{\mathrm{n}}$ values were 10.49 and $10.20 \mathrm{MJ} \mathrm{kg}^{-1}$ for each phase.
\end{abstract}

Keywords: biodiesel, by-product, metabolism, poultry

\section{RESUMO}

Os valores energéticos da glicerina bruta $(G B)$ foram determinados para frangos de corte em diferentes idades, por meio da utilização do método proposto por Matterson e de regressões polinomiais. Foram realizados dois ensaios: de 11 a 21 dias e de 31 a 41 dias de idade das aves; em ambos, as aves foram distribuídas em um delineamento experimental inteiramente ao acaso, com uma ração referência $(R R)$, sem GB, e três rações testes com substituição de 5\%, 10\% e 15\% da RR por GB. Foram calculados os valores de energia metabolizável pelo método de Matterson, sendo os valores de energia metabolizável aparente (EMA) utilizados na análise de regressão polinomial. Os valores médios da EMA corrigida pelo balanço de nitrogênio $\left(E M A_{n}\right)$, o coeficiente de metabolizabilidade da EB (CMAEB) e o corrigido para o balanço de nitrogênio $\left(C M A E B_{n}\right)$ da $G B$, na matéria natural, para a fase de 11 a 21 dias, pelo método de Matterson, foram de 10,08 $\mathrm{MJ} \mathrm{kg}^{-1}, 10,04 \mathrm{MJ} \mathrm{kg}^{-1}, 67,06 \%$ e 66,74\%, respectivamente. A inclusão de GB apresentou um efeito linear crescente para os CMAEB e os CMAEB ${ }_{n}$. Na fase de 31 a 41 dias, foram de 10,38 $\mathrm{MJ} \mathrm{kg}^{-1}, 10,27 \mathrm{MJ} \mathrm{kg}^{-1}, 69,02 \%$ e 62,24\%, respectivamente. Por meio das equações de regressões polinomiais, o valor de EMAn estimada foi de 10,49 $\mathrm{MJ} \mathrm{kg}^{-1}$ e 10,18 $\mathrm{MJ} \mathrm{kg}^{-1}$, respectivamente. Os valores de $\mathrm{EMA}_{n}$ da GB para as idades 11 a 21 e 31 a 41 dias foram de 10,04 MJ kg-1 e 10,26 $\mathrm{MJ} \mathrm{kg}^{-1}$, respectivamente. De acordo com as equações propostas por Matterson e com o método de Adeola, os valores de $\mathrm{EMA}_{n}$ foram 10,49 e 10,20 $\mathrm{MJ} \mathrm{kg}^{-1}$ para cada fase.

Palavras-chave: avicultura, biodiesel, subproduto, metabolismo

Recebido em 7 de outubro de 2019

Aceito em 18 de agosto de 2020

E-mail: cleisondsz@hotmail.com 


\section{INTRODUCTION}

Corn is the main energetic ingredient in the diet of non-ruminants, comprising $60 \%$ to $70 \%$ of the diet. However, it presents great price variation due to the off-season period, drought, ethanol production and its use in human food, which ends up burdening livestock production (Min et al., 2010; Ferreira et al., 2014; Zavarize et al., 2014). As a result, there is a growing search for alternative ingredients to be used in animal production that can replace those commonly used in the diets, thus reducing the production costs and increasing the supply of these cereals to other sectors of the industry. Crude glycerin (CG), a byproduct of biodiesel production, it is one of these possible substitutes.

CG is generated in the biodiesel production process, representing about $10 \%$ of the material obtained (Swiatkiewicz and Koreleski, 2009). After going through the refinement process, it can be employed in the pharmaceutical industry, the production of cosmetics, the military, and the food industry (Sehu et al., 2012). In this sense, research has been developed with the purpose of analyzing the use of glycerin in its crude form as an alternative to energetic foods in the diet of nonruminant animals, thus avoiding the refinement process (Silva et al., 2012; Henz et al., 2014).

The average value of gross energy (GE) of CG according to the amount of residual ether extract is $15.07 \mathrm{MJ} \mathrm{kg}^{-1}$ (Cerrate et al., 2006). According to Dozier et al. (2008) and Jung and Batal (2011), the glycerol metabolizable coefficient is between $80 \%$ and $99 \%$. Despite being an economically attractive energy ingredient, the chemical and mineral composition of glycerin varies between samples (Lammers et al., 2008; Zavarize et al., 2014). According to Kerr et al. (2009), glycerol energy is related to glycerol, methanol, and fatty acid composition. The variation of energy between samples occurs due to its degree of purity, which varies as stated to the techniques and equipment used in biodiesel production (Lammers et al., 2008).

The values of metabolizable energy of the ingredients can be calculated by several methods, with the equations proposed by Matterson et al. (1965) being the most used. However, the ingredients energetic values can be influenced by several factors, such as inclusion levels, age, the sex of the birds, and the methodology used in metabolism trials (Bertelt and Schneider, 2002; Kunrath et al., 2010). Another method for the determination of energy is the Adeola method (2000), which evaluates the slope of the line to determine the energetic value of the ingredients, with the main advantage of using polynomial regression equations involving multiple levels of inclusion. Thus, the objective of this study was to determine the energetic values (AME and $\mathrm{AME}_{\mathrm{n}}$ ) of CG through the methods of Matterson et al. (1965) and Adeola (2000), as well as their respective metabolizable coefficients for broilers at different ages.

\section{MATERIAL AND METHODS}

Two experiments were conducted at the Poultry Research Center of the Experimental Station of the Western Paraná State University - Unioeste, Marechal Cândido Rondon, Paraná, Brazil. The CG used was derived from biodiesel production and was purchased from the company BIOPAR ${ }^{\circledR}$ - Bioenergia of Paraná Ltda, based in Rolândia, Paraná, Brazil. Experimental birds were handled with care to avoid unnecessary discomfort and all experimental procedures were approved by the University ethical review committee (protocol \#21/13).

The experiments were carried out in metabolic cages to determine the energy values of $\mathrm{CG}$ for broiler chickens from 11 to 21 days and from 31 to 41 days of age. Samples of CG were sent to the Laboratory of Animal Nutrition to determine gE, mineral matter (MM), potassium (K), and sodium $(\mathrm{Na})$, according to the techniques described by Silva and Queiroz (2006). Additional samples were sent to the Food Laboratory of the Technological Institute of Paraná (Tecpar) for the determination of moisture content using the Karl Fischer method and the contents of glycerol and methanol by the gas chromatographic method.

In the first experiment, 200 male broilers, Cobb 500 , from 11 to 21 days of age were used. In the second, 100 male broilers, Cobb 500, from 31 to 41 days of age were used. In both experiments, the treatments were distributed in a completely randomized experimental design, with one reference ration (RR) and three test rations, in which the RR was substituted at the levels of 5\%, $10 \%$, and $15 \%$ by CG, totaling four treatments, with five replicates of 10 and five birds per 
experimental unit, respectively. The reference diet was formulated based on corn and soybean meal, according to the recommendations of Rostagno et al. (2011), to meet the nutritional requirements of each period (Table 1).

Table 1. Chemical and energetic composition of the reference diet used in the metabolism assays (11 to 21 and 31 to 41 days of age)

\begin{tabular}{|c|c|c|}
\hline Ingredient $\left(\mathrm{g} \mathrm{kg}^{-1}\right)$ & 11 to 21 days & 31 to 41 days \\
\hline Corn & 567.8 & 662.7 \\
\hline Soybean meal (45\%) & 359.5 & 276.7 \\
\hline Soybean oil & 33.50 & 30.00 \\
\hline Monocalcium phosphate & 13.60 & 9.47 \\
\hline Limestone & 12.75 & 9.94 \\
\hline Salt & 4.82 & 4.42 \\
\hline Vitamin $^{1}$ & 1.00 & 1.00 \\
\hline Mineral $^{2}$ & 0.50 & 0.50 \\
\hline L-LysinehCL (78\%) & 2.40 & 2.24 \\
\hline DL-Methionine (99\%) & 3.12 & 2.36 \\
\hline L-Threonine $(99 \%)$ & 0.81 & 0.47 \\
\hline BHT & 0.20 & 0.20 \\
\hline \multicolumn{3}{|c|}{ Nutrient specification $\left(\mathrm{g} \mathrm{kg}^{-1}\right)$} \\
\hline Met. En. (MJ kg-1) & 12.78 & 13.19 \\
\hline Crude protein & 212.0 & 181.2 \\
\hline Calcium & 8.41 & 6.38 \\
\hline Available phosphor & 4.01 & 2.98 \\
\hline Dig. lysine & 12.17 & 10.10 \\
\hline Dig. met + cyst & 8.76 & 7.37 \\
\hline Dig. threonine & 7.91 & 6.56 \\
\hline Dig. Tryptophane & 2.37 & 1.94 \\
\hline Chlorine & 3.40 & 3.18 \\
\hline Sodium & 2.10 & 1.95 \\
\hline Potassium & 8.22 & 6.98 \\
\hline
\end{tabular}

${ }^{1}$ Vitamin premix for broilers (BR00014639). Levels per kilogram product (min): Vit. A (Retinol Acetate, min) 9,000,000UI, Vit. D3 (Colecalciferol, min) 2,500,000UI, Vit. E (Alpha-tocopheryl acetate, min) 200,000UI, Vit. K3 (Menadiona Sodium Bisulfite, min) 2,500mg, Vit. B1 (Thiamine mononitrate, min) 1,500mg, Vit. B2 (Riboflavin, min) 6,000mg, Vit. B6 (Pyridoxinehydrochloride, min) 3,000mg, Vit. B12 (Cyanocobalamin, min) 12,000 $\mu$ g. Pantothenic acid (Calcium pantothenate, min) 12g, Niacin (Nicotinic acid, min) 25g, Folic acid (min) 800mg, Biotin (D-biotin, min) 60mg and Selenium (Sodium selenite, min) 250mg. ${ }^{2}$ Mineral premix for broilers (BR00013863). Levels per kilogram product: Copper (Copper sulphate, $\min$ ) 20g, Iron (Iron Sulphate, min) 100g, Manganese (Manganese Sulfate, $\mathrm{min}$ ) 160g, Cobalt (min) 2,000mg, Iodine (Calcium Iodate, min) 20,00mg and Zinc (Zinc sulfate, min) 100g.

The birds were at 10 and 30 days of age when they were transferred to metabolism cages, receiving water and feed ad libitum throughout the experimental period. The values of apparent metabolizable energy (AME) and apparent corrected by the nitrogen balance $\left(\mathrm{AME}_{\mathrm{n}}\right)$ of the glycerin for the different ages were determined by the total excreta collection method (Sibbald and Slinger, 1963). The experimental period lasted 10 days, with five days of adaptation and five days of collection, performed twice a day, with an interval of $12 \mathrm{~h}$, to avoid fermentation. At the time of collection, the trays were covered with plastic and placed under the cages to avoid losses and contamination, and the excreta were placed in plastic bags and stored in a freezer at $-20^{\circ} \mathrm{C}$.

At the end of the experimental period, the feed intake and the total amount of excreta produced by each experimental unit were determined. After the excreta were defrosted and homogenized, a sample of approximately $200 \mathrm{~g}$ of each replicate was pre-dried in a forced-ventilation oven at $55^{\circ} \mathrm{C}$ for $72 \mathrm{~h}$ for determination of the dry air sample. After pre-drying, the samples were ground to perform dry matter (DM), GE, and nitrogen (N) analyses. Based on the results of the analyses and using the equations proposed by Matterson et al. 
(1965), the $\mathrm{AME}$ and $\mathrm{AME}_{\mathrm{n}}$ values were calculated. After determination of the ME values, the metabolizable coefficients of crude energy were calculated for the test feed. Using the method proposed by Adeola (2000), the mean values of the $A M E_{n}$ of $C G$ were estimated by means of a linear regression equation for later comparison with the values of $\mathrm{AME}_{\mathrm{n}}$ of $\mathrm{CG}$ found by the method of Matterson et al. (1965).

Statistical analysis was performed using a variance analysis and subsequent polynomial regression between inclusion levels for apparent metabolizable coefficients of gross energy (CAMEB) and those corrected for the nitrogen balance $\left(\mathrm{CAMEB}_{\mathrm{n}}\right)$, excluding RR (0\% of CG). Statistical analyzes of the metabolizable coefficients were performed using the statistical procedure PROCGLM of statistical software SAS (2017) student version.

\section{RESULTS}

The chemical composition of the CG evaluated in the experiment are shown in Table 2.
Table 2. Nutritional characterization of crude glycerin used in experimental diets in natural matter

\begin{tabular}{lc}
\hline \multicolumn{1}{c}{ Composition $\left(\mathrm{g} \mathrm{kg}^{-1}\right)$} & Crude glycerin \\
\hline Dry matter & 903.0 \\
Glycerol & 881.0 \\
Crude protein & 2.0 \\
Gross energy $\left(\mathrm{MJ} \mathrm{kg}^{-1}\right)$ & 15.03 \\
Methanol & 37.6 \\
Mineral matter & 53.0 \\
Sodium & 9.8 \\
Potassium & 0.3 \\
\hline
\end{tabular}

In the period from 11 to 21 days of age, there was no difference $(\mathrm{P}>0.05)$ for $\mathrm{AME}$ and $\mathrm{AME}_{\mathrm{n}}$ values. However, the inclusion of CG presented a linear increasing effect $(\mathrm{P}<0.05)$ for $\mathrm{CAMEB}$ and CAMEB $_{n}$, indicating a better use of GE contained in $C G$ with the increased inclusion of $C G$ in the diet. For the period from 31 to 41 days of age, $\mathrm{AME}, \mathrm{AME}_{\mathrm{n}}, \mathrm{CAMEB}$, and $\mathrm{CAMEB}_{\mathrm{n}}$ showed no difference $(\mathrm{P}>0.05)$ between inclusion levels of CG (Table 3).

Table 3. Energy values and metabolizable coefficients of crude glycerin for broilers at different ages fed with different levels of glycerin inclusion expressed on the basis of natural matter

\begin{tabular}{|c|c|c|c|c|}
\hline Inclusion $(\%)$ & AME $\left(\mathrm{MJ} \mathrm{kg}^{-1}\right)$ & $\mathrm{AME}_{\mathrm{n}}\left(\mathrm{MJ} \mathrm{kg}^{-1}\right)$ & CAMEB (\%) & $\mathrm{CAMEB}_{\mathrm{n}}(\%)$ \\
\hline \multicolumn{5}{|c|}{11 to 21 days old } \\
\hline 5 & 9,28 & 9,23 & 61.75 & 61.38 \\
\hline 10 & 10,48 & 10,44 & 69.70 & 69.41 \\
\hline 15 & 10,48 & 10,44 & 69.72 & 69.42 \\
\hline Average & 10,08 & 10,04 & 67.06 & 66.74 \\
\hline SEM & 55.73 & 51.65 & 1.55 & 1.44 \\
\hline $\mathrm{P}$ (Regression) & - & - & $0.02(\mathrm{~L})$ & $<0.01(\mathrm{~L})$ \\
\hline \multicolumn{5}{|c|}{31 to 41 days old } \\
\hline 5 & 10,40 & 10,28 & 69.14 & 68.36 \\
\hline 10 & 10,51 & 10,30 & 69.92 & 68.52 \\
\hline 15 & 10,22 & 10,20 & 67.98 & 67.84 \\
\hline Average & 10,38 & 10,26 & 69.02 & 68.24 \\
\hline EPM & 37.17 & 33.23 & 1.03 & 0.93 \\
\hline $\mathrm{P}$ (Regression) & - & - & 0.68 & 0.84 \\
\hline \multicolumn{4}{|c|}{ Polynomial Regression Equations } & $\mathrm{R}^{2}$ \\
\hline \multicolumn{4}{|c|}{$\mathrm{CAMEB}_{(11 \text { to } 21)}=59.0914+0.796887 \mathrm{CG}$} & 0.75 \\
\hline \multicolumn{4}{|c|}{$\mathrm{CAMEB}_{\mathrm{n}(11 \text { to } 21)}=58.7027+0.803804 \mathrm{CG}$} & 0.74 \\
\hline
\end{tabular}

AME: apparent metabolizable energy; $\mathrm{AME}_{\mathrm{n}}$ : apparent metabolizable energy corrected for nitrogen balance; CAMEB: coefficient of apparent metabolizability of gross energy; $\mathrm{CAMEB}_{\mathrm{n}}$ : coefficient of apparent metabolizability of crude energy corrected for nitrogen balance; $\mathrm{Q}=$ quadratic; $\mathrm{L}=$ linear.

According to the method suggested by Adeola (2000) to obtain $\mathrm{AME}_{\mathrm{n}}\left(\mathrm{MJ} \mathrm{kg}^{-1}\right)$ from $\mathrm{CG}$, we estimated the slope of the linear relationship between the consumption of $\mathrm{AME}_{\mathrm{n}}$ vs. the consumption of $\mathrm{CG}$, resulting in the equations $\mathrm{AME}_{\mathrm{n}}=10,49 * \mathrm{CG}-0,0703\left(\mathrm{R}^{2}=0.99\right)$ and $\mathrm{AME}_{\mathrm{n}}$ $=10,181 * \mathrm{CG}+0,0152\left(\mathrm{R}^{2}=0.99\right)$ for stage 11 to 21 days of age and stage 31 to 41 days of age, 
respectively. The predicted $\mathrm{AME}_{\mathrm{n}}$ value was $10.49 \mathrm{MJ} \mathrm{kg}^{-1}$ and $10.18 \mathrm{MJ} \mathrm{kg}^{-1}$.

\section{DISCUSSION}

The lack of standardization of processes and the variation of raw materials used in biodiesel production are directly associated with the chemical composition of CG (Zavarize et al., 2014). In this context, it is necessary to determine the levels of methanol, glycerol, $\mathrm{Na}$ and ethereal extract (free fatty acids) of the samples, since it can affect the values of ME (Jung and Batal, 2011). The GE value of CG (15.03 $\mathrm{MJ} \mathrm{kg}^{-1}$ ) resembles the value of maize (16.32 $\left.\mathrm{MJ} \mathrm{kg}^{-1}\right)$, according to Rostagno et al. (2017). The efficiency of the biodiesel production process determines the energy value of CG samples, when there is better use of fatty acids in the process, the GE of the glycerin is lower. On the other hand, CG has a higher GE when there is inefficiency in the production process, which results in an increase in the concentration of residues in $\mathrm{CG}$, mainly fatty acids (Penz and Gianfelice, 2008).

The values found for the humidity and the glycerol content of the CG used in this study are in accordance with the standards issued by the Ministry of Agriculture (Ministério..., 2010). For glycerin to be used in animal feed, it must contain no more than $12 \%$ moisture and a minimum content of $80 \%$ glycerol. However, the methanol content of the sample $(3.76 \%)$ was above the value stipulated by the MAPA which is $0.015 \%$.

Data presented in the literature show great variation regarding the chemical composition between different CG samples. Oliveira et al. (2013), when analyzing 41 CG samples from 16 Brazilian companies from three different raw materials, found values ranging from $30.4 \%$ to $90.1 \%$ for glycerol, $0.8 \%$ to $26.6 \%$ for moisture, $0 \%$ to $37.7 \%$ for total lipids, $2.3 \%$ to $12.1 \%$ for $\mathrm{MM}, 6.1 \mathrm{~g}$ to $28.2 \mathrm{~g} \mathrm{~kg}^{-1}$ for $\mathrm{Na}$, and $\mathrm{pH}$ of 2.3 to 12.7. Similarly, Kerr et al. (2009), analyzing samples obtained from different companies and raw materials in the USA, observed that the samples presented variation from $51 \%$ to $83 \%$ for glycerol, $0.005 \%$ to $14 \%$ for methanol, and $0.02 \%$ to $35 \%$ for fatty acids.

The concentrations of methanol, $\mathrm{Na}$, and $\mathrm{K}$ in $\mathrm{CG}$ samples depend on the procedures used during the extraction of biodiesel and during the purification of glycerol (Zavarize et al., 2014). According to Soffritti et al. (2002), when accumulated in the body, methanol can cause blindness, central nervous system depression, vomiting, severe metabolic acidosis, as well as locomotor problems in animals. Another concern in the use of CG is the $\mathrm{Na}$ content, since this can lead to an electrolytic imbalance in birds (Cerrate et al., 2006). Mushtaq and Pasha (2013) emphasize that electrolyte balance is dependent on $\mathrm{Na}, \mathrm{K}$, chlorine, bicarbonate, and some proteins. Electrolyte balance can affect appetite, response to thermal stress, bone development, growth, utilization of minerals, amino acids, and vitamins (Bezerra et al., 2013). However, the CG sample evaluated in this study had low concentration of $\mathrm{Na}$ and $\mathrm{K}$ with levels of $0.98 \%$ and $0.03 \%$, respectively.

The energy value of CG, according to Henz et al. (2014), may vary according to its level of inclusion in the diet, as well as other factors such as the age and sex of the animals. In addition, the composition of CG may influence its energetic value, such as, its content of glycerol, fatty acids, and methanol (Dozier et al., 2011). The CAMEB presented linear behavior decreasing for the first period evaluated, and increasing for the last phase, with mean values of $75.10 \%, 85.50 \%$, and $82.84 \%$, respectively, for each phase.

Jung and Batal (2011) evaluating 10 CG samples from different industries observed an inversely proportional relationship between the percentage of glycerol and fat and methanol content. According to the authors, the higher concentration of glycerol in the samples, the lower fat and methanol levels. Henz et al. (2014) determined the AME of CG for broilers from 11 to 20, 21 to 30 , and 31 to 40 days of age and observed mean values of 14.04, 15.97, and $15.35 \mathrm{MJ} \mathrm{kg}^{-1}$ of $\mathrm{AME}_{\mathrm{n}}$, respectively for each period evaluated.

The study by Borsatti et al. (2018) with purified glycerin (99\% glycerol), found $\mathrm{AME}_{\mathrm{n}}$ values of $16.40 \mathrm{MJ} \mathrm{kg}^{-1}$, while França et al. (2014) reported 16.04 and $16.33 \mathrm{MJ} \mathrm{kg}^{-1}$ of $\mathrm{AME}_{\mathrm{n}}$ in broilers with 19 and 34 days of age, respectively, using free methanol glycerol. According to Dozier et al. (2008), the AME value of CG has a positive correlation with the percentage of glycerol. Besides the evidence, this correlation was not observed in this experiment. The CG evaluated has ahigh percentage of glycerol, however, the 
$A M E_{n}$ value was lower than other results found in the literature, demonstrating according to Borsatti et al. (2018) that the energetic value of CG can be influenced by other factors besides the glycerol content.

When evaluating CG samples from soybean oil, Dozier et al. (2011) observed that samples with a concentration of fatty acids lower than $0.5 \%$ have $\mathrm{CAMEB}_{\mathrm{n}}$ of approximately $97.4 \%$, whereas in samples that had $25 \%$ to $30 \%$ of fatty acids, CAMEB $_{n}$ was $65.6 \%$, indicating that glycerin with high free fatty acid content has lower digestibility by birds. Zavarize et al. (2014) determining the $\mathrm{AME}_{\mathrm{n}}$ of four CG samples from different companies in Brazil for 21-day-old broilers, found energetic values of 13.17; 21.05; 11.17; and $12.11 \mathrm{MJ} \mathrm{kg}^{-1}$ with $\mathrm{CAMEB}_{\mathrm{n}}$ of $90 \%$, $81 \%, 72 \%$, and $85 \%$. This high energy value can be explained by the fatty acid levels of the sample. It is assumed that the digestibility of fat can be reduced when there is ahigh concentration of free fatty acids in its composition (Gaiotto et al., 2000).

The values found for $\mathrm{AME}_{\mathrm{n}}$ at the different ages between the methods used were very similar, since, by the formulas proposed by Matterson et al. (1965), the value of $\mathrm{AME}_{\mathrm{n}}$ was 10.04 and $10.26 \mathrm{MJ} \mathrm{kg}^{-1}$, and by the Adeola method the $\mathrm{AME}_{\mathrm{n}}$ values were 10.49 and $10.20 \mathrm{MJ} \mathrm{kg}^{-1}$, respectively, for the phases of 11 to 21 days of age and 31 to 41 days of age. According to Kunrath et al. (2010), the method used to determine the energy values of ingredients, among other factors, may affect the results obtained. Thus, the use of the method proposed by Adeola (2000), although already used in pig farming at a certain time, appears as another tool to determine the value of $\mathrm{AME}_{\mathrm{n}}$ when evaluating poultry feed. An advantage of this method is the ability to generate a more accurate value, since it uses the regression analysis estimated from several levels of inclusion, rather than just estimating by level, as in the Matterson method.

Dozier et al. (2008) carried out three experiments to determine the value of $\mathrm{AME}_{\mathrm{n}}$ from a sample of CG for birds at different ages (7 to 10, 21 to 24 , and 42 to 45 days of age) and obtained the values of $11.46,12.47$, and $12.69 \mathrm{MJ} \mathrm{kg}^{-1}$ by the traditional method and 15.16, 13.95 and $14.02 \mathrm{MJ}$ $\mathrm{kg}^{-1}$ by the method proposed by Adeola (2000), respectively.

\section{CONCLUSION}

The mean of $\mathrm{AME}_{\mathrm{n}}$ and $\mathrm{CAMEB}_{\mathrm{n}}$ determined between 11 to 21 and 31 to 41 days of age for $\mathrm{CG}$ were $10.04 \mathrm{MJ} \mathrm{kg}^{-1}, 66.74 \%, 10.26 \mathrm{MJ} \mathrm{kg}^{-1}$ and $68.24 \%$, respectively, according to the equations proposed by Matterson. According to Adeola's method, AMEn values were 10.49 and $10.20 \mathrm{MJ}$ $\mathrm{kg}^{-1}$ for each phase.

\section{REFERENCES}

ADEOLA, O. Digestion and balance techniques in pigs. In: LEWIS, A.J.; SOUTHERN, L.L. Swine nutrition. 2.ed. Boca Raton: CRC Press, 2000. p.903-916.

BARTELT, J.; SCHNEIDER, D. Investigation on the energy value of glycerol in the feeding of poultry and pig. Union for the Promotion of Oilseeds-Schriften Heft, v.17, p.15-36, 2002.

BEZERRA, R.M.; FREITAS, E.R.; NASCIMENTO, G.A.J. et al. Níveis de cloro para codornas japonesas em crescimento e seus efeitos na fase de produção. Semin. Ciênc. Agrár., v.34, p.853-862, 2013.

BORSATTI, L.; VIEIRA, S.L.; STEFANELLO, C.; KINDLEIN, L.; OVIEDO-RONDÓN, E.O.; ANGEL, C.R. Apparent metabolizable energy of by-products from the soybean oil industry for broilers: acidulated soapstock, glycerin, lecithin, and their mixture. Poult. Sci., v.97, p.124-130, 2018.

CERRATE, S.; YAN, F.; WANG, Z. et al. Evaluation of glycerine from biodiesel production as a feed ingredient for broilers. Int. J. Poult. Sci., v.11, p.10011007, 2006.

DOZIER, W.A.; KERR, B.J.; BRANTON, S.L. Apparent metabolizable energy of crude glycerin originating from different sources in broiler chickens. Poult. Sci., v.90, p.2528-2534, 2011.

DOZIER, W.A.; KERR, B.J.; CORZO, A. et al. Apparent metabolizable energy of glycerin for broiler chickens. Poult. Sci., v.87, p.317-322. 2008.

FERREIRA, A.H.C.; LOPES, J.B.; ABREU, M.L.T. et $a l$. Whole scrapings of cassava root in diets for broilers from 1 to 21 days of age. Acta Sci. Anim. Sci., v.36, p.357-362, 2014.

FRANÇA, A.M.S.; FERNANDES, E.A.; RAMOS, G.C.; FAGUNDES, N.S. Determinação da energia metabolizável do glicerol desmetanolizado para frangos de corte em diferentes fases de criação. Vet. Notícias, v. 20, p.44-51, 2014.

GAIOTTO, J.B.; MENTEN, J.F.M.; RACANICCI, A.M.C. et al. Óleo de soja, óleo ácido de soja e sebo bovino como fontes de gordura em rações de frangos de corte. Rev. Bras. Cienc. Avic., v.2, p.219-227, 2000. 
HENZ, J.R.; NUNES, R.V.; EYNG, C. et al. Energia metabolizável da glicerina bruta para frangos de corte de diferentes idades. Semin. Ciênc. Agrár., v.35, p.3393-3400, 2014.

JUNG, B.; BATAL, A.B. Nutritional and feeding value of crude glycerin for poultry. 1. Nutritional value of crude glycerin. J. Appl. Anim. Res., v.20, p.162-167, 2011.

KERR, B.J.; WEBER, T.E.; DOZIER, W.A.; KIDD, M.T. Digestible and metabolizable energy content of crude glycerin originating from different sources in nursery pigs. J. Anim. Sci., v.87, p.4042-4049, 2009.

KUNRATH, M.A.; KESSLER, A.M.; RIBEIRO, A.M.L. et al. Metodologias de avaliação do valor nutricional do farelo de arroz desengordurado para suínos. Pesqui. Agropecu. Bras., v.45, p.1172-1179, 2010

LAMMERS, P.J.; KERR, B.J.; WEBER, T.E. et al. Digestible and metabolizable energy of crude glycerol for growing pigs. J. Anim. Sci., v.86, p.602-608, 2008.

MATTERSON, L.D.; POTTER, L.M.; STUTZ, M.W.; SIGSEN, E.P. The metabolizable energy of feed ingredients for chickens. Res. Rep. Conn. Agric. Exp. Stn., v.7, p.11-14, 1965.

MIN, Y.N.; YAN, F.; LIU, F.Z. et al. Glycerin - a new energy source for poultry. Int. J. Poult. Sci., v.9, p.1-4, 2010

MINISTÉRIO da agricultura autoriza novo uso da glicerina. Brasília: MAPA, 2016. Disponível em: http://www.sindiracoes.org.br/index.php?option=com content\&task=view\&id=972. Acessado em: 26 fev. 2016.

MUSHTAQ, M.M.H.; PASHA, T.N. Electrolytes, dietary electrolyte balance and salts in broilers: an updated review on acid-base balance, blood and carcass characteristics. Worlds Poult. Sci. J., v.69, p.833-852, 2013.

OLIVEIRA, J.S.; ANTONIASSI, R.; FREITAS, S.C.; MÜLLER, M.D. Composição química da glicerina produzida por usinas de biodiesel no Brasil e potencial de uso na alimentação animal. Cienc. Rural, v.43, p.509-512, 2013.
PENZ JUNIOR, A.M.; GIANFELICE, M. O que fazer para substituir os insumos que podem migrar para a produção de biocombustível. Acta Sci. Vet., v.36, p.107-117, 2008.

ROSTAGNO, H.S.; ALBINO, L.F.T.; DONZELE, J.L. et al. Tabelas brasileiras para aves e suínos: composição de alimentos e exigências nutricionais. 4.ed. Viçosa: UFV, 2017. 252p.

ROSTAGNO, H.S.; ALBINO, L.F.T.; DONZELE, J.L. et al. Tabelas brasileiras para aves e suínos: composição de alimentos e exigências nutricionais. 3.ed. Viçosa: UFV, 2011. 252p.

SAS Institut. SAS/STAT Users Guide. University Edition. SAS Inst. Inc., Cary, NC, 2017.

SEHU, A.; KUCUKERSAN, S.; COSKUN, B. et al. Effects of dietary glycerol addition on growth performance, carcass traits and fatty acid distribution in cloacal fat in broiler chickens. Rev. Med. Vet., v.163, p.194-200, 2012.

SIBBALD, I.R.; SLINGER, S.J. A biological assay for metabolizable energy in poultry feed ingredients together with findings which demonstrate some of the problems associated with the evaluation of fats. Poult. Sci., v.42, p.313-325, 1963

SILVA, C.L.S.; MENTEN, J.F.M.; TRALDI, A.B. et $a l$. Glycerine derived from biodiesel production as a feedstuff for broiler diets. Rev. Bras. Cienc. Avic., v.14, p.159-232, 2012.

SILVA, D.J.; QUEIROZ, J.S. Análise de alimentos (métodos químicos e biológicos). 3.ed. Viçosa: UFV, 2006. 235p.

SOFFRITTI, M.; BELPOGGI, F.; CEVOLANI, D. et al. Results of long-term experimental studies on the carcinogenicity of methyl alcohol and ethyl alcohol in rats. Ann. N. Y. Acad. Sci., v.982, p.46-69, 2002.

SWIATKIEWICZ, S.; KORELESKI, J. Effect of crude glycerin level in the diet of laying hens on egg performance and nutrient utilization. Poult. Sci., v.88, p.615-619, 2009.

ZAVARIZE K.C.; MENTEN, J.F.M.; PEREIRA, R. et al. Metabolizable energy of different glycerine sources derived from national biodiesel production for broilers. Braz. J. Poult. Sci., v.16, p.411-416, 2014. 